\section{Decolourisation of ReActive BlaCk 5 by KLEBSiella PNEUMONIAE ISOLATEd From ANTARCTICA SEAWATER}

\author{
Ameerah Tharek, Bay Hui Han, Shaza Eva Mohamad, Zaharah Ibrahim* \\ Malaysia-Japan International Institute of Technology (MJIIT), Universiti \\ Teknologi Malaysia Kuala Lumpur, Jalan Semarak, 54100 Kuala Lumpur, \\ Malaysia
}

Article history

Received

9 April 2017

Received in revised form

1 July 2017

Accepted

10 September 2017

*Corresponding author zaharah@utm.my

\section{Graphical abstract}

Screening of bacteria from Antarctica seawater

for RB5 decolourisation decolourisation

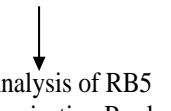
decolourisation Products

FTIR, HPLC, ammonia test and carbon dioxide test

\begin{abstract}
The discharge of highly coloured azo dyes effluent has caused serious environmental damages. In this study, bacteria isolated from Antarctica seawater were screened for their ability to decolourise azo dye Reactive Black 5 (RB5). The selected bacterium was further investigated to study its ability to decolourise RB5. The best bacteria from Antarctica seawater that had the ability to decolourise RB5 was identified using 16S rDNA sequence analysis and revealed that the bacteria 15C shared $99 \%$ homology to Klebsiella pneumoniae. Selection of the most effective bacteria was followed by its acclimatisation to decolourise higher concentrations of RB5 by growing it in successively higher concentrations of RB5. Following that, optimization of RB5 decolourisation by the selected bacteria was performed using one factor at time (OFAT) including concentration of dye, $\mathrm{pH}$ and temperature. The results obtained indicated the optimal condition for decolourisation of RB5 using this bacterium was at $\mathrm{pH} 10$ and $37^{\circ} \mathrm{C}$ in $70 \mathrm{mg} / \mathrm{L}$ RB5 with $98 \%$ decolourisation within $24 \mathrm{~h}$ under facultative anaerobic treatment. Besides that, $70 \%$ of COD removal was achieved after $96 \mathrm{~h}$ of sequential anaerobic and aerobic treatment of RB5. In addition, FTIR and HPLC were used to analyze the metabolite of RB5 decolourisation. Products of RB5 decolourisation was confirmed by the presence of sulphanilic acid in HPLC analyses and the changes observed in the functional groups of the FTIR spectrum suggesting the possibility of RB5 degradation. Ammonia test and carbon dioxide test showed higher concentration of ammonia and carbon dioxide that indicates the mineralisation of product after treatment.
\end{abstract}

Keywords: Azo dye, Reactive Black 5, decolourisation, Klebsiella pneumonia, Antarctica seawater

\begin{abstract}
Abstrak
Pembuangan azo pewarna efluen yang tinggi telah menyebabkan kerosakan alam sekitar yang serius. Dalam kajian ini, bakteria dari air laut Antartika telah disaring untuk keupayaan mereka untuk menyahwarnakan azo pewarna Reaktif Hitam 5 (RB5). Bakteria yang telah dipilih ini dikaji dengan lebih lanjut keupayaannya untuk menyahwarnakan RB5. Identiti bakteria yang paling berkesan untuk menyahwarnakan RB5 telah dikenalpasti dengan menggunakan 16S rDNA sequence analisis dan analisis ini menunjukkan strain bakteria 15C adalah Klebsiella pneumoniae dengan $99 \%$ persamaan. Pemilihan bakteria yang paling berkesan itu seterusnya telah disuaikan untuk menyahwarnakan kepekatan RB5 yang tinggi dengan menumbuhkan bakteria ini di dalam kepekatan RB5 yang tinggi. Selepas itu, pengoptimuman RB5 penyahwarnaan oleh bakteria yang terpilih telah dilakukan dengan satu factor pada satu masa (OFAT) termasuk kepekatan pewarna, pH dan suhu. Keputusan yang diperolehi menunjukkan yang penyahwarnaan RB5 adalah paling berkesan pada $\mathrm{pH} 10$ dan $37^{\circ} \mathrm{C}$ dalam $70 \mathrm{mg} / \mathrm{L}$ RB5. Penyahwarnaan yang dioptimumkan ini telah mencapai $98 \%$ penyahwarnaan RB5 selepas 24 jam inkubasi fakultatif anaerobik. Selain itu, $70 \%$ pengurangan COD telah dicapai selepas 96 jam rawatan anaerobik dan aerobik. Di samping itu, FTIR dan HPLC telah digunakan untuk menganalisis metabolit penyahwarnaan RB5. Penyahwarnan RB5 telah disahkan dengan kehadiran asid sulphanilic dalam HPLC analisis dan perubahan yang berlaku dalam spektrum FTIR. Ujian ammonia dan karbon dioksida menunjukkan pembentukkan kepekatan ammonia dan karbon dioksida yang tinggi menunjukkan mineralisasi produk selepas rawatan RB5.
\end{abstract}

Kata kunci: Azo dye, Reactive Black 5, penyahwarnaan, Klebsiella pneumonia, air laut Antartika (C) 2017 Penerbit UTM Press. All rights reserved 


\subsection{INTRODUCTION}

Nowadays, more than 100,000 new synthetic dyes are used in textile, cosmetic, paper, leather, pharmaceutical, food, and other industries, with a worldwide annual consumption of about 735 tons [1]. These textile industries create problems to the environment involving textile wastewater effluent. The main problems of textile industries are associated with the discharge and the degradation of the synthetic textile dye to the environment which can be considered as a worldwide problem [2]. Synthetic textile dyes can be classified as the most dangerous pollutants as it is a part of the industrial effluents which contaminate higher amount of river water [3]. The soluble or insoluble dyes which are used in textile industries are synthetic and have complex aromatic structure. Azo dyes are among the largest class of chemical dyes used [4].

Azo dyes have been used extensively for textile dyeing and paper painting [5]. The annual world production of azo dyes is estimated to be around one million tons and more than 2000 structurally different azo dyes are currently in use [6]. However, approximately 10 to $15 \%$ of the dye used does not bind to fibers, depending on the structure and is released into sewage treatment systems or the environment during the dyeing process [1]. The discharge of these highly coloured industrial effluents to the environment causes public concern, serious environmental and health hazards as well as legislation problems [7]. Colour is the first indicator of pollution which is recognized in the wastewater and has to be removed before discharging into environments. The presence of dyes in aqueous environments causes interruption of penetration of dissolved oxygen and sunlight into deeper layers of water and hence lowering the photosynthetic activity and water quality [3]. Toxic compounds from dye effluent are absorbed into aquatic organisms then pass through the food chain and finally reach human population causing many damages such as risk of cancer and food poisoning [8].

Toxicity of the dyes varies with azo dye structures and is also related to the type of intermediates used in their synthesis. After reduction or cleavage of the azo bond, aromatic amines are formed, which are more toxic than the parent azo dye compounds [9]. Therefore, treating textile wastewater is very important as the dyes are visible even at low concentration due to the presence of colour and it destroys the aesthetics of the water [10]. Decolourisation of textile dyes is possible using physical and chemical methods such as adsorption, oxidation, coagulationflocculation, chemical degradation and photodegradation [11]. Some of these methods have effectively removed the colour. However, the treatments are costly and not adaptable to a wide range of dye wastewaters [12]. They generate significant amounts of chemical sludge waste whose disposal in a secure landfill increases processing cost [4].

Conversely, biological processes have received increasing interest due to their low cost, effectiveness, ability to produce less sludge and being environmental friendly [13], [14]. It is known that several microorganisms such as fungi, bacteria and algae can decolourise many azo dyes [15]. These microorganisms have developed enzyme system for the decolourisation and mineralisation of azo dyes under certain environmental conditions [16], [15], [17]. Since numerous bacterial species including Bacillus, Pseudomonas, Enterobacter, Halobacter, and Aeromonas have been reported to exhibit tremendous potential to decolourize and detoxify a wide range of azo dyes [18], this research will focus on bacterial decolourisation.

\subsection{METHODOLOGY}

\subsection{Reactive Black 5 (RB5)}

Reactive Black 5 stock solution was prepared by dissolving $2.5 \mathrm{~g}$ of Reactive Black 5 powder from SIGMA ALDRICH into $100 \mathrm{~mL}$ of sterilised distilled water. Then, the stock solution was filtered using nylon filter $0.2 \mu \mathrm{M}$. The stock solution was then diluted to desired working concentration.

\subsection{Screening of Bacterial Strain}

All the bacteria from Antarctica seawater that has been isolated were initially screened in a nutrient broth containing azo dye Reactive Black 5 in order to identify the colour removing bacteria. The decolourisation was monitored visually for 7 days under facultative anaerobic and aerobic conditions. Under aerobic condition, $50 \mathrm{~mL}$ of decolourising medium were transferred into a conical flask $(250 \mathrm{~mL})$ and $10 \%(v / v)$ inoculums was added and incubated at $20^{\circ} \mathrm{C}$ with shaking. Under facultative anaerobic condition, $50 \mathrm{~mL}$ of decolourising medium was added into falcon tube $(50 \mathrm{~mL})$ and $10 \%(\mathrm{v} / \mathrm{v})$ of inoculums were added and incubated at $20^{\circ} \mathrm{C}$ without shaking. Then, bacterium that had the highest decolourisation of Reactive Black 5 were further characterized on the pattern of decolourisation by time.

\subsection{Acclimatisation of Bacteria in RB5}

Initially the $10 \%(\mathrm{v} / \mathrm{v})$ bacterial culture was transferred into $50 \mathrm{~mL}$ of decolourising medium containing $5 \mathrm{mg} / \mathrm{L}$ of RB5 dye solution in a falcon tube. The falcon tube was subsequently sealed and incubated for $48 \mathrm{~h}$ interval under static condition. This procedure was repeated at intervals of $48 \mathrm{~h}$. The acclimatisation procedure was continued using higher concentrations (10 mg/L-100 mg/L) of Reactive Black 5 which were increased in steps of $25 \mathrm{mg} / \mathrm{L}$ every 5 days till 30 days. 


\subsection{Identification of Dye Decolorizing Bacteria}

The bacterial strain with the highest decolourising activity was further identified using 165 rDNA sequence analysis. Genomic DNA from selected strain was extracted using GF-1 Bacterial DNA Extraction Kit. The 16S rRNA gene PCR amplications was performed by using a pair of universal primers (Forward primer: 5' AGA GTT TGA TCC TGG CTC AG 3' and Reverse primer: 5' GGT TAC CTT GTT ACG CCT T 3'). Sequencing of PCR products was sent to Genomics Bioscience and Technology Co. The search for existing sequences similar to the sequence obtained was done through the Basic Local Alignment Search Tool for nucleotide (BLASTn) programs provided by NCBI.

\subsection{Optimization of Reactive Black 5 Decolourisation}

Optimization of Reactive Black 5 decolourisation by the selected bacteria that had highest decolourisation was performed on several parameters using one factor at time (OFAT). The treatment was conducted to optimize 3 parameters; initial dye concentration, $\mathrm{pH}$ and temperature.

\subsection{Decolourisation Analysis}

The sample was centrifuged for 15 minutes at $4000 \mathrm{rpm}$ and the supernatant was collected. The supernatant obtained was used to determine the percentage of decolourisation by measuring the absorbance at the wavelength of $597 \mathrm{~nm}$ (The maximum absorption wavelength for RB5 dye) using $\mathrm{HACH}$ spectrophotometer. The percentage of decolourisation was calculated using the following formula:

Decolourisation (\%) = Initial Dye Concentration-Observed Dye Concentration X $100 \%$ Initial Dye Concentration

\subsection{Chemical Oxygen Demand (COD) Analysis}

COD reagent $(0.75 \mathrm{~mL})$ was added into sample (1.0 $\mathrm{mL}$ ) followed by $1.75 \mathrm{~mL}$ acid reagent in a $\mathrm{HACH}$ refluxing vial. The mixture sample was refluxed at $150^{\circ} \mathrm{C}$ for $2 \mathrm{~h}$ using a heater. The sample was then let to cool down for 30 minutes. COD value was determined using a $\mathrm{HACH}$ spectrophotometer and distilled water was used as a blank (HACH, 1997).

\subsection{Analysis of RB5 Decolourisation Products}

The product of decolourisation of RB5 was analysed using FTIR, HPLC, ammonia test and carbon dioxide test.

\subsubsection{Fourier Transform Infrared Spectroscopy (FTIR)}

Biodegradation of Reactive Black 5 was characterized by FTIR and compared with control dye. The control and the supernatant of samples were dried using rotary vacuum evaporator and mixed with equal volume of methanol. Then, the samples and control dye were mixed with $\mathrm{KBr}$. The spectra were collected within a scanning range of $400-4000 \mathrm{~cm}^{-1}$ with 32 scan speed. The FTIR was first calibrated for background signal scanning with a control sample of pure $\mathrm{KBr}$, and then the experimental sample was scanned. The FTIR spectrum of the control was finally subtracted from the spectra of the non-degraded and degraded dyes.

\subsubsection{High Performance Liquid Chromatography (HPLC)}

After decolourisation, the product of RB5 decolourisation were centrifuged for 15 minutes at $4000 \mathrm{rpm}$ and supernatants were collected. Then, equal volume of methanol was added to the supernatants and dried in a rotary vacuum evaporator. The dried samples were dissolved in $2 \mathrm{~mL}$ of methanol and filtered through syringe filter 10.20 $\mu \mathrm{m}$ ). The samples were analysed by HPLC (model waters 600) equipped with auto sampler (717 plus) and dual wavelength UV detector (model waters 2487) at $254 \mathrm{~nm}$ and with a C18 column (5 $\mu \mathrm{m}, 4.6$ $\mathrm{mm} \times 250 \mathrm{~mm}$ ). The mobile phase consisted of mixture of methanol and nano pure water in the ratio of 75:25 $(\mathrm{v} / \mathrm{v})$. The samples were eluted isocratically at a flow rate of $0.7 \mathrm{ml} / \mathrm{min}$. The standard solution used to detect the biodegradation product was sulphanilic acid.

\subsubsection{Carbon Dioxide Test}

Carbon dioxide test was used to identify the presence of $\mathrm{CO}_{2}$ in the sample. A volume of $6.5 \mathrm{~mL}$ of sample was diluted 10 times with distilled water and transferred into $\mathrm{HACH}$ vial. One drop of phenolphthalein indicator solution was added. Then sodium hydroxide solution was added drop by drop until the colour of sample changes to light pink which indicates for the presence of $\mathrm{CO}_{2}(\mathrm{HACH}, 1985)$.

\subsubsection{Ammonia Test}

Ammonia test was used for determination of ammonia compounds. A volume of $15 \mathrm{~mL}$ of sample was prepared by diluting 10 times with distilled water. Then, 3 drops of mineral stabiliser and 3 drops of polyvinyl alcohol dispersing agent was added to the sample and the mixture was mixed by shaking manually. After that, $1.0 \mathrm{~mL}$ of Nessler reagent was added to the samples. 


\subsection{RESULTS AND DISCUSSION}

\subsection{S rDNA Analysis}

16S rDNA analysis revealed that a bacteria strain 15C was $99 \%$ similar matches to Klebsiella pneumoniae (Accession number: NR 074913.1). The $16 \mathrm{~S}$ rDNA sequence was aligned using Blast (NCBI) with the reference sequences from other 16S rDNA sequences obtained from Gene Bank (NCBI).

\subsection{Biological Treatment of Reactive Black 5 under Optimized Condition}

Figure 1 shows decolourisation of RB5 using acclimatised bacteria 15C under sequential facultative anaerobic-aerobic conditions. Under optimized condition at temperature $37^{\circ} \mathrm{C}$ in $70 \mathrm{mg} / \mathrm{L}$ of RB5 concentration of $\mathrm{pH} \mathrm{10,} \mathrm{the} \mathrm{decolourisation} \mathrm{of}$ RB5 reached $98 \%$ within $24 \mathrm{~h}$ under facultative anaerobic condition. However, decolourisation of RB5 dropped to $94 \%$ during the aerobic phase.

Decolourisation of RB5 was better under anaerobic condition because, during anaerobic phase, without interference from oxygen molecules, electrons were transferred to the azo group to break the azo bond which is a natural electron acceptor. Azo dye acts as electron acceptor and organic matters in medium act as electron donor. ATP is generated during this catabolic breakdown of organic compound in medium and resultant electrons are directly accepted by azo dye due to absence of oxygen, no competitive substrate is present. As electrons are accepted by azo dye the azo double bond cleave off resulting decolourisation [19]. Therefore, anaerobic condition almost completely decolourise the dye.

However, further treatment is required to completely mineralize the carcinogenic aromatic amines. These colourless aromatic amines are biodegradable under aerobic condition [19] but less effective in decolourisation compared to anaerobic condition. This is because the azo dye could not act as electron acceptor from the NADH in electron transport chain in the presence of oxygen molecules, because the oxygen is a stronger oxidizing agent and would act as electron acceptor [20]. The presence of oxygen in the medium is competing with azo groups for electrons.

In order to evaluate the mineralisation efficiency of the process, Chemical Oxygen Demand is carried out. Percentage of COD removal at the end of anaerobic treatment during the first $24 \mathrm{~h}$ was $30 \%$. However, after the treatment under aerobic condition, percentage of COD removal increased to $70 \%$. The low COD removal during anaerobic phase was due to the presence of end product of biodegradation which might have toxic or inhibitory effect on the bacterial culture. Besides that, because there is no oxygen consumed in the process there is only a little reduction in COD in anaerobic process. The COD removal increased during aerobic phase due to the high mineralisation rate of the aromatic compounds [21]. It was also reported that aerobic treatment acts as a polishing step to provide higher pollutant removal such as COD and toxic substances. [22].

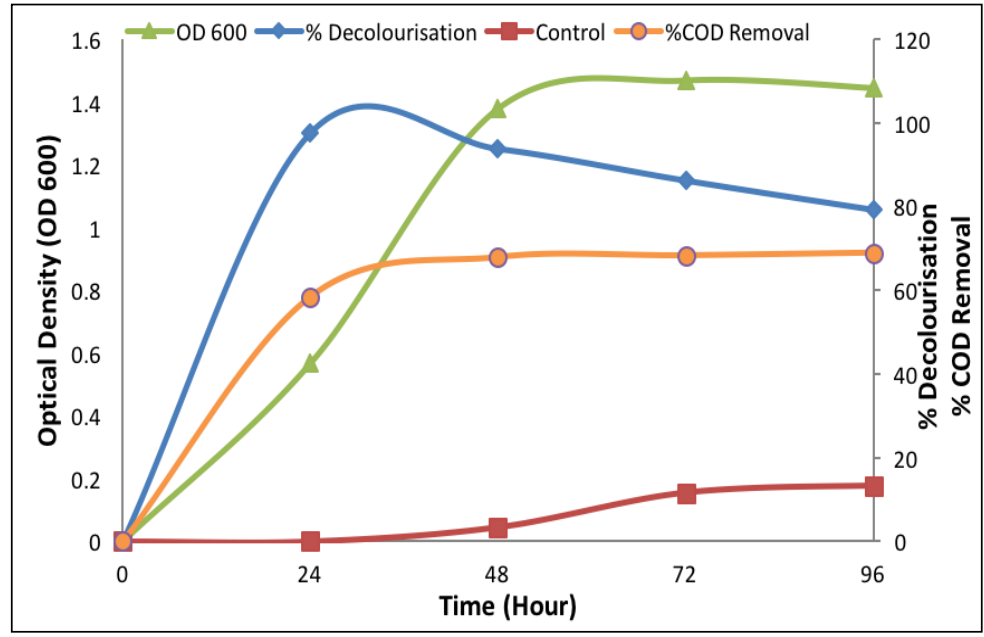

Figure 1 Decolourisation of Reactive Black 5 (RB5) and COD Removal under optimized condition $\left(\mathrm{pH} 10,37^{\circ} \mathrm{C}, 70\right.$ ppm) 


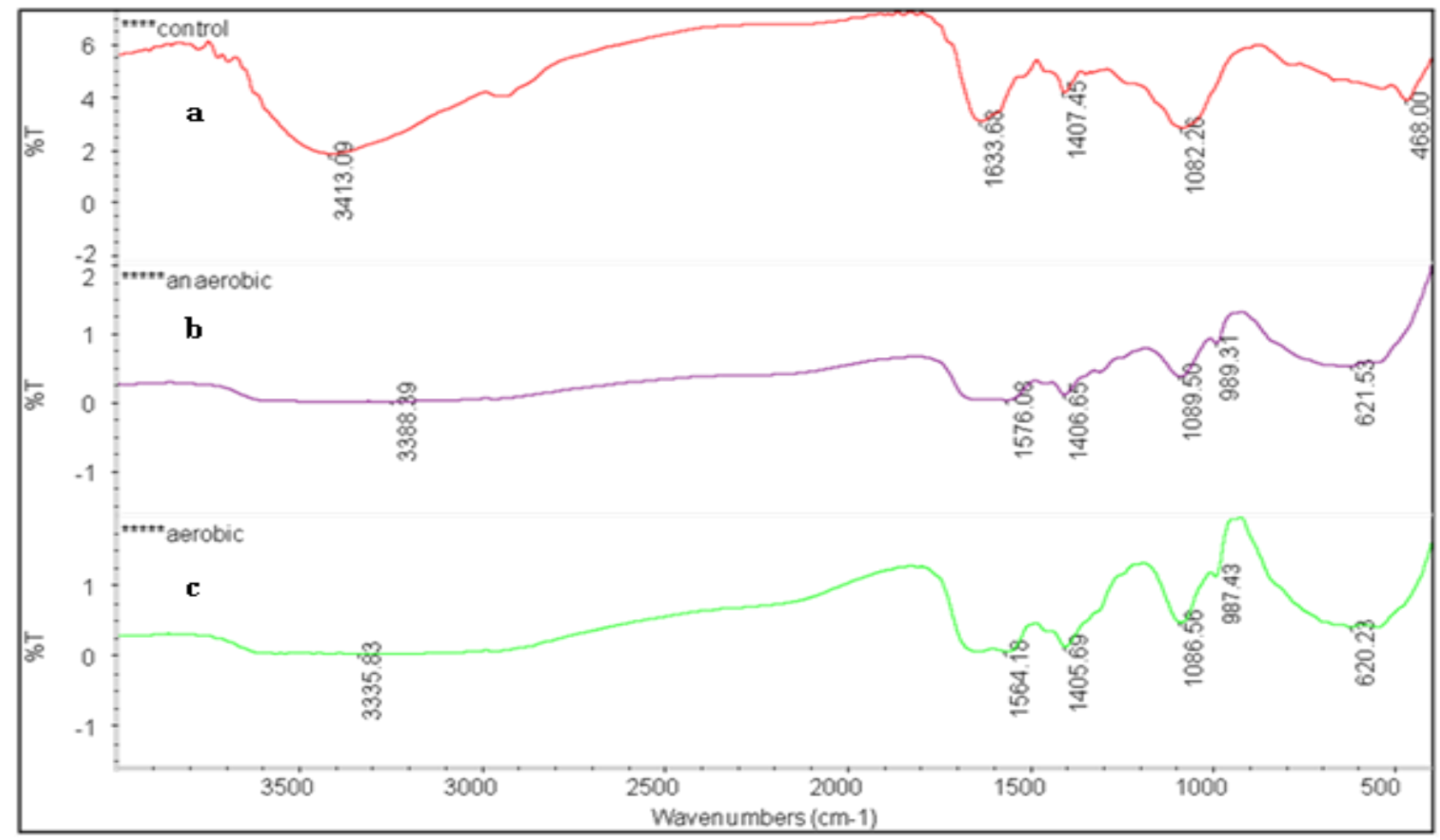

Figure 2 FTIR spectra of dye RB5 and its metabolites obtained during sequential facultative anaerobic-aerobic biodegradation. (a) Control of RB5 (b) RB5 after anaerobic treatment (c) RB5 after aerobic treatment

\subsection{Analysis of Product of RB5 Decolourisation}

The functional groups present in the samples were identified using Fourier transform infrared spectroscopy (FTIR) and the product of decolourisation of RB5 was analysed using HPLC. Carbon dioxide and ammonia produced after mineralisation of aromatic amines were determined by using $\mathrm{CO}_{2}$ test and ammonia test.

\subsubsection{Fourier Transform Infrared Spectroscopy Analysis (FTIR)}

Based on FTIR result in Figure 2, the FTIR spectra of untreated RB5 display a peak at $3413.09 \mathrm{~cm}^{-1}$ region where $\mathrm{N}-\mathrm{H}$ stretching as in amines and $\mathrm{O}-\mathrm{H}$ stretching as in alcohols is normally observed. While, the adsorption band at $1633.68 \mathrm{~cm}^{-1}$ region is attributed to $\mathrm{C}=\mathrm{C}$ stretching as in alkene. The band at $1407.45 \mathrm{~cm}^{-1}$ is due to azo $(-\mathrm{N}=\mathrm{N}-)$ bond stretching. Coates (2000) reported that the band near 1,407.45 $\mathrm{cm}^{-1}$ was due to azo linkage stretching in a substituted compounds. A peak near to $1080 \mathrm{~cm}^{-}$ 1 for $\mathrm{S}=\mathrm{O}$ indicates sulfinic acid. FTIR spectrum of treated RB5 presented some significant variations in the position of all peak when compared to the control RB5.

The peak at $3413.09 \mathrm{~cm}^{-1}$ untreated RB5 shows a band shift to a very broad peak after treatment. This broad peak indicates $\mathrm{O}-\mathrm{H}$ stretching as in carboxylic acid. The reason of $\mathrm{O}-\mathrm{H}$ stretch of carboxylic acid is so broad because carboxylic acid usually exists as hydrogen bond dimer. While spectrum at peak $1633.68 \mathrm{~cm}^{-1}$ that represent for alkene and peak at $1407.45 \mathrm{~cm}^{-1}$ region due to azo linkage of untreated RB5 shows a slight band shift decrease in intensity of band after anaerobic and aerobic treatment of RB5.

Moreover, a peak near to region $1082.26 \mathrm{~cm}^{-1}$ that represent for sulfinic acid shows increase in intensity of band after anaerobic treatment of RB5. This may be due to the production of sulphanilic acid as decolourised metabolite after anaerobic treatment. After aerobic treatment, peak that represent for sulfinic acid decrease a bit. This might be due to the autoxidation or mineralisation of sulphanilic acid that occurred after this treatment.

Besides that, FTIR spectrum of treated dye also showed the appearance of new peak near to region $980 \mathrm{~cm}^{-1}$ and $620 \mathrm{~cm}^{-1}$, representing $\mathrm{C}-\mathrm{H}$ bending as in alkane. Thus, the changes observed in the spectrum of untreated RB5 and treated RB5 suggest biodegradation of RB5 had most probably occurred. 

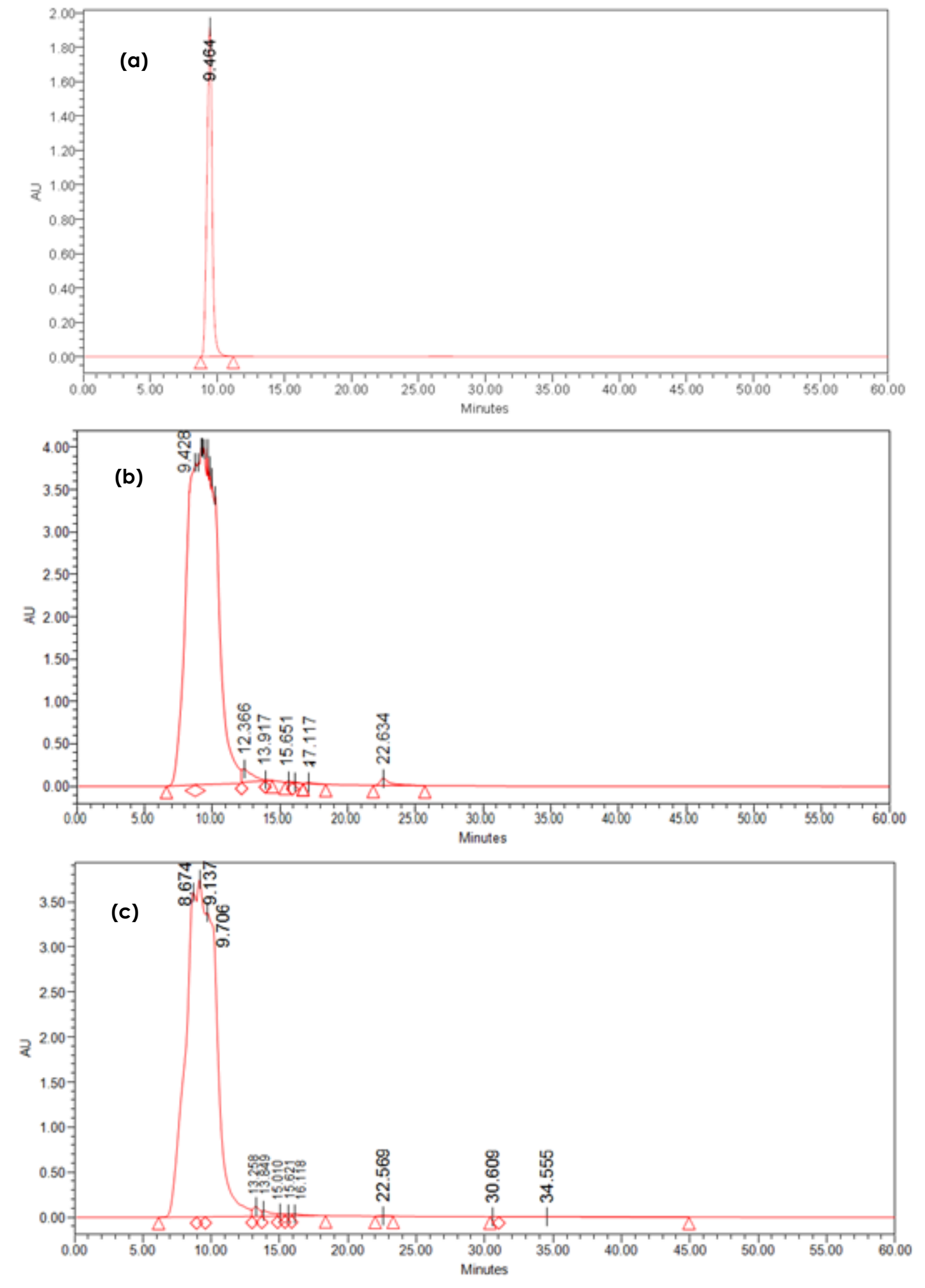

Figure 3 HPLC analysis of RB5 degradation (a) Sulphanilic acid standard (b) Anaerobic treatment of RB5 (c) Aerobic treatment of RB5 


\subsubsection{High Performance Liquid Chromatography Analysis (HPLC)}

The main degradation products of Reactive Black 5 under anaerobic condition are sulphanilic acid and triaminohydroxynapthalene disulphanilic acid [23]. Therefore, the sulphanilic acid as a product of RB5 degradation after anaerobic treatment were analysed using HPLC. Sulphanilic acid was used as a standard to compare its retention time (RT) with decolourised sample. During the $96 \mathrm{~h}$ of sequential facultative anaerobic and aerobic treatment, possible biodegradation products were analysed using HPLC. The RT of standard sulphanilic acid was $9.464 \mathrm{~min}$ as shown in Figure 3 (a). The chromatogram in Figure 3 (b) showed peak with RT 9.428 almost similar to that of standard sulphanilic acid as shown in Figure 3 (a). This is possible since sulphanilic acid is one of the decolourised metabolites that can be produced during treatment of RB5 under facultative anaerobic condition. Peak at RT 12.366, 13.917, 15.651 and 17.117 minutes were also detected in facultative anaerobic treatment.

The absorbance of peak with RT 9.428 minute as shown in Figure 3 (b) was slightly decreased to absorbance of peak with RT 9.137 minute in aerobic treatment as shown in Figure 3 (c). This may be due to the depletion of sulphanilic acid after aerobic treatment. The depletion of sulphanilic acid was mainly due to the mineralisation or autoxidation of sulphanilic acid and biotransformed to other possible intermediates.

New peak at RT 30.609 and RT 34.555 were form during aerobic treatment were possibly be the products of autoxidation resulted from decolourised metabolites undergoing biodegradation or autoxidation reaction under subsequent aerobic treatment.

\subsubsection{Carbon Dioxide Test}

Carbon dioxide $\left(\mathrm{CO}_{2}\right)$ test quantifies the $\mathrm{CO}_{2}$ produced during the colorant mineralisation by the microorganisms. After the aerobic treatment of RB5 $200 \mathrm{mg} / \mathrm{L}$ of $\mathrm{CO}_{2}$ was produced while negative result was observed during facultative anaerobic.

During oxidation of aromatic amine that produced during decolourisation under anaerobic treatment of RB5, the product formed would cleave as a carboxylic acid. Then, the carboxylic acid would undergo further oxidation which would then probably oxidise to $\mathrm{CO}_{2}$. Besides that, some of the substrate in the sample might be completely oxidised to harmless end product of $\mathrm{CO}_{2}, \mathrm{H}_{2} \mathrm{O}$ or other inorganic substances to provide energy for growth of the microorganisms. Thus, this test proved that mineralisation process occurred as $\mathrm{CO}_{2}$ was shown to be produced during autoxidation of RB5.

\subsubsection{Ammonia Test}

Based on the result, the concentration of ammonia produced was highest during oxidation of RB5 in aerobic treatment with $1100 \mathrm{mg} / \mathrm{L}$ of ammonia compared to $340 \mathrm{mg} / \mathrm{L}$ ammonia produced during facultative anaerobic. Before degradation of RB5 by microorganism, the concentration of ammonia produced showed the lowest with $23 \mathrm{mg} / \mathrm{L}$ of ammonia. Aromatic amines are derivatives of ammonia with one or more alkyl groups bonded to the nitrogen. The highest concentration of ammonia produced after oxidation of RB5 indicated the mineralisation of aromatic amine into simpler form.

\subsection{CONCLUSION}

Sequential facultative anaerobic-aerobic decolourisation of RB5 using Klebsiella pneumonia showed effective decolourisation at $\mathrm{pH} 10$ and $37^{\circ} \mathrm{C}$ in $70 \mathrm{mg} / \mathrm{L}$ RB5 with decolourisation of $98 \%$ within $24 \mathrm{~h}$. Further analysis decolourisation of RB5 confirmed the presence of sulphanilic acid, higher concentration of ammonia and $\mathrm{CO}_{2}$ after sequential facultative anaerobic-aerobic treatment which indicates the degradation of RB5 and mineralisation of aromatic amine.

\section{Acknowledgement}

We would like to thank Faculty of Bioscience and Medical Engineering (FBME) for providing the funding and space for the work to be carried out.

\section{References}

[1] Sedigheh Asad, Seyed Mohammad Mehdi Dastgheib, Mohammad Ali Amoozegar. 2014. Optimization for Decolorization of Azo Dye Remazol Black B by a Halomonas Strain Using the Taguchi Approach. Progress in Biological Sciences. 4(1): 33-42.

[2] Siti Aishah Mohd Hanim. 2012. Optimization of Decolourization of Reactive Black 5 using Brevibacillus Panacihumi. Master Thesis. Universiti Teknologi

[3] Shertate, R. S. and Thorat, P. R. 2013. Decolorization and Biodegradation of Textile Azo Dye Sunset Yellow FCF by Acclimatized Marine Bacteria. Indian Streams Research Journal. 3(2): 2230-7850.

[4] Shahid Mahmood, Muhammad Arshad, Azeem Khalid, Zilli Huma Nazli and Tariq Mahmood. 2011. Isolation and Screening of Azo Dye Decolorizing Bacterial Isolates from Dye-contaminated Textile Wastewater. Soil Science Society of Pakistan. 30(1): 7-12.

[5] N. Mahesh Kumar and D. Saravanan. 2015. Isolation of Dye Degrading Bacteria from Textile Effluent. Journal of Chemical and Pharmaceutical Research. 7(3): 2214-2218.

[6] Vijaykumar, M.H., P.A. Vaishampayan, Y.S. Shouche and T. B. Karegoudar. 2007. Decolourization of NaphthaleneContaining Sulfonated Azo Dyes by Kerstersia sp. Strain VKY1. Enzyme and Microbial Technology. 40: 204-211. 
[7] Cheng, K. C., Wu, J. Y., Liou, D. J. and Hwang, S. C. J. 2003. Decolorization of the Textile Azo Dyes by Newly Isolated Bacterial Strains. J. Biotechnol. 101: 57-68.

[8] Puvaneswari, N., Muthukrishnan, J. and Gunasekaran, P. 2006. Toxicity Assessment and Microbial Degradation of Azo Dyes. Indian Journal of Experimental Biology. 44: 618626.

[9] Hildenbrand, S., Schmahl, F. W. and Wodarz R. 1999. Azo Dyes and Carcinogenic Aromatic Amines in Cell Culture. Int Arch Occup Environ Health. 72: M52.

[10] Gomez, V., Larrenchi, M. S. and Callao, M. P. 2007. Kinetic and Adsorption Study of Acid Dye Removal Using Activated Carbon. Chemosphere. 69: 1151-1158.

[11] G. Donmez. 2002. Bioaccumulation of The Reactive Textile Dyes by Candida Tropicalis Growing in Molasses Medium. Enzyme Microb. Technol. 30: 363-366.

[12] I.M Banat. P. Nigam, D. Singh, R. Marchant. 1996. Microbial Decolourisation of Textile Dye Containing Efflunts. A Review, Bioresour. Technol. 58: 217-227.

[13] Y.Fu, T. Viraghavaan. 2001. Fungal Decolorization of Dye Wastewaters: A Review. Bioresour. Technol. 79: 251-262.

[14] Z. Aksu. 2005. Application of Biosorption for the Removal of Organic Pollutants. A Review. Process Biochem. 40: 9971026.

[15] Pandey, A., P. Singh and L. Lyengar. 2007. Bacterial Decolourisation and Degradation of Zo Dyes. International Biodeterioration and Biodegradation. 59: 73-84.

[16] Hao, J. J., F. Q. Song, F. Huang, C. L. Yang, Z. J. Zhang, Y. Zheng and X. J. Tian. 2007. Production of Laccase by a Newly Isolated Deuteromycete Fungus Pestalotiopsis Sp. and Its Decolorization of Azo Dye. Journal of Industrial Microbiology and Biotechnology. 34: 233-240.

[17] Khalid, A., M. Arshad and D. E. Crowley. 2008. Accelerated Decolorization of Structurally Different Azo Dyes by Newly Isolated Bacterial Strains. Applied Microbiology and Biotechnology. 78: 361-369.

[18] Hassan, M. M., Alam, M. Z. and Anwar, M. N. 2013. Biodegradation of Textile Azo Dyes by Bacteria Isolated from Dyeing Industry Effluent. Int. Res. J. Biological Sci. 2(8): 2278-3202.

[19] Cırık, Kevser, and Özer Çınar. 2010. Parameters Affecting Anaerobic Color Removal of Textile Wastewaters. 2nd International Symposium on Sustainable Development, June 8-9 2010, Sarajevo. 571-578.

[20] Dafale, N., L. Agrawal, A. Kapley, S. Meshram, H. Purohit, S. Wate. 2010. Selection of Indicator Bacteria based on Screening of 165 rDNA Metagenomic Library from a TwoStage Anoxic-oxic Bioreactor System Degrading Azo Dyes. Bioresource Technology. 101: 476-484.

[21] Kapdan, K. I., Tekol, M. and Sengul, F. 2003. Decolorization of Simulated Textile Wastewater in an Anaerobic Aerobic Sequential Treatment System. Process Biochem. 38: 1031-7.

[22] Ilgi Karapinar Kapdan. 2005. Kinetic Analysis of Dyestuff and COD Removal from Synthetic Wastewater in an Anaerobic Packed Column Reactor. Process Biochemistry. 40: 2545-2550.

[23] Chang, J. S. and Kuo, T. S. 2000. Kinetics of Bacterial Decolorization of Azo Dye with Escherichia coli. Bioresource Technology. 75(2): 107-111. 